\title{
Role of anti-oxidants to reduce free radical induced injury in preeclampsia
}

\author{
Nidhi Tripathi, Amrita Singh*, Kiran Pandey, Neetu Singh, Sangeeta Arya
}

Department of Obstetrics and Gynaecology, GSVM Medical College, Kanpur, Uttar Pradesh, India

Received: 23 June 2016

Revised: 30 September 2016

Accepted: 01 October 2016

\section{* Correspondence:}

Dr. Amrita Singh,

E-mail: amrita.5511@ rediffmail.com

Copyright: () the author(s), publisher and licensee Medip Academy. This is an open-access article distributed under the terms of the Creative Commons Attribution Non-Commercial License, which permits unrestricted non-commercial use, distribution, and reproduction in any medium, provided the original work is properly cited.

\section{ABSTRACT}

Background: The aim of study is to study role of antioxidants to reduce free radical induced oxidative stress in preeclampsia.

Methods: A prospective study conducted with 326 patients in UISEMH, Kanpur at Department of Obstetrics and Gynaecology from January 2011 - January, 2012 with 326 patients. There were divided into 2 groups - control and study group on the basis of measurement of activity of superoxide dismutase at 20 weeks, control group constituted patients with normal SOD level (Normal values $>0.702 \mathrm{U} / \mathrm{mg}$ of protein). Study group constituted 180 patients with decreased SOD level at 20 weeks, they were further divided into 2 groups - study group A and study group B, according to intervention given in form of Vit. C $1000 \mathrm{mg}$ OD from 20 weeks till delivery. SOD was re-measured in control and study group at 32 weeks. Result was studied in terms of value of SOD at 32 weeks and incidence of PIH and IUGR, mode of delivery, complications in forms of mild and severe PET, Abruptio placentae, antepartum eclampsia and IUGR.

Results: The study showed that mean level of SOD at 20 weeks in study group was much less as compared to control group, also SOD value in group A at 32 weeks is much less as compared to group B in which intervention was given $\mathrm{t}$ value $\sim 46.877, \mathrm{p}$ value $<0.0001 ; 95 \%$ CI $-0.285223-0.310391$, which is statistically highly significant. Hence, in our study there was statistically significant improvement in SOD enzyme levels after giving intervention in study group.

Conclusions: Since, preeclampsia is multifactorial disorder in which oxidative stress plays very important role in pathophysiology amongst various other factors. The antioxidant supplementation to such patients who already have reduced anti-oxidant status definitely has role in decreasing incidence of PIH and its severity.

Keywords: Anti-oxidants, Preeclampsia

\section{INTRODUCTION}

Acute pancreatitis in pregnancy (APIP) is rare and occurs Pregnancy Induced Hypertension includes gestational hypertension Pre-eclampsia, eclampsia, superimposed Preeclampsia on chronic hypertension and chronic hypertension. In a healthy body, reactive oxygen species and antioxidants remain in balance, when balance is disrupted towards an overabundance of ROS, oxidative stress occurs. It plays a role during pregnancy, normal parturition, recurrent pregnancy loss, initiation of preterm labour, anaemia, pre-eclampsia, eclampsia, IUGR. ${ }^{1}$

There are 2 types of free radical species:

1. Reactive Oxygen species - superoxide's, hydrogen peroxides and hydroxyl

2. Reactive Nitrogen species - NO 
Antioxidants are molecules that inhibit oxidation of other molecules in plants and animals, they maintain complex systems of multiple- types of antioxidants such as glutathione, Vit $\mathrm{C}, \mathrm{A}$ and $\mathrm{E}$ as well as enzymes such as catalase, SOD and various peroxidase, insufficient levels of antioxidants or inhibition of antioxidant enzymes, cause oxidative stress and may damage or kill cells.

Two types of defence system against these free radicals:

1. Enzymatic

2. Non-enzymatic

Enzymatic comprises - i) Superoxide dismutase ii) Catalase iii) Glutathione Reductase

The reduction of SOD activity could result in an impaired protection against toxic effects of Oxidants and thus might lead to cellular damage.

Non-enzymatic - Ascorbic Acid, Vit C, Vit E, Lycopene. $\mathrm{PIH}$ is associated with constriction of uterine Blood vessels, pathological changes in spiral arterioles and fibrin deposition and other pathological changes in placenta, resulting in retarded fetal growth, fetal hypoxia, and intrauterine fetal death.

Superoxide radicals in and around vascular endothelial cells, play a critical role in the pathogenesis of hypertension. The putative misalliance of fetal trophoblast with maternal tissue in uteroplacental vascular bed may give rise to increase in oxygen free radicals. These form link between immunological maladaptation and endothelial damage known to occur in pre-eclampsia. Oxygen free Radicals and lipid peroxides decrease vascular prostacyclin and EDRF release and increase thromboxane $\mathrm{A}_{2}$ and endothelin release. ${ }^{2}$

Mean actively of SOD in pre-eclamptic placenta was significantly lower than as compared to SOD in Normal term placenta.

Based on these mechanisms, it was proposed that there could be role of antioxidant supplementation in the patients with already reduced antioxidant status that is who show decreased SOD levels.

The study analysed that antioxidant supplementation when given at 18-20 weeks of gestation till delivery, had a role in the patients who already have depleted SOD levels.

\section{METHODS}

A prospective study conducted with 326 patients in UISEMH Kanpur Department of Obstetrics and Gynaecology from January 2011 - January, 2012.

The subjects of the present study were divided into 2 groups:
1. The control group included 146 patients with normal SOD level at 20 weeks. Normal value of SOD is taken as $\geq 0.702 \mathrm{U} / \mathrm{mg}$ of protein.

2. The study group - Included 180 patients with decreased SOD level at 20 weeks and were further divided into 2 groups on the basis of intervention given in form of Vit C $1000 \mathrm{mg}$ 1OD starting from 20 weeks onwards till delivery.

\section{Inclusion criteria}

Gestational age $\leq 20$ weeks

Or else previous pregnancy complicated by PIH.

\section{Exclusion criteria}

Patients with gestational age $>20$ weeks, with diabetes Renal Insufficiency, essential hypertension.

Routine physical examination and antenatal investigations were conducted and specific investigation for SOD measurement was done.

\section{RESULTS}

During study period from January 2011 to January 2012, 326 patients were studied.

Table 1: Age and BMI distribution of study patients.

\begin{tabular}{|lll|}
\hline Group & $\begin{array}{l}\text { Mean age } \\
\text { with SD }\end{array}$ & $\begin{array}{l}\text { Mean BMI with } \\
\text { SD }\end{array}$ \\
\hline Control & $24.03 \pm 2.61$ & $22.8 \pm 1.278$ \\
\hline Study & & \\
Without intervention & $24.54 \pm 2.83$ & $22.59 \pm 1.303$ \\
With intervention & $24.61 \pm 2.78$ & $22.81 \pm 1.396$ \\
\hline
\end{tabular}

The mean age and BMI of control as well as study group are almost same. Thus age and BMI cannot be a confounding factor. Mean age of control and study group was taken- 24 years and mean BMI of both groups was also same- 22.6.

Table 2: Mean SOD with standard deviation in study group before and after treatment.

\begin{tabular}{|lll|}
\hline & $\begin{array}{l}\text { Mean value of } \\
\text { OSD at 20 weeks } \\
\text { before treatment }\end{array}$ & $\begin{array}{l}\text { Mean SOD at 32 } \\
\text { weeks after } \\
\text { treatment }\end{array}$ \\
\hline Control & $0.73366 \pm 0.005205$ & $0.63791 \pm 0.153091$ \\
\hline $\begin{array}{l}\text { Study A } \\
\text { without } \\
\text { intervention }\end{array}$ & 0.50631 & 0.36529 \\
\hline $\begin{array}{l}\text { Study B } \\
\text { with } \\
\text { Intervention }\end{array}$ & 0.51523 & 0.66310 \\
\hline
\end{tabular}


Mean value of SOD at 20 weeks in control group was 0.73366 and at 32 weeks -0.6379 .

In study group A and B mean value of SOD at 20 weeks is 0.50631 and 0.51523 respectively, after giving intervention in group B, value of SOD at 32 weeks is 0.36529 and 0.66310 respectively in $\mathrm{A}$ and $\mathrm{B}$. T- test was applied to table 3 and statistically highly significant results were obtained with $\mathrm{T}$-test value $0.0001 .95 \% \mathrm{CI}$, 0.285223-0.310391, mean difference 0.297807.

Table 3: Incidence of PIH in various groups before and after treatment.

\begin{tabular}{|c|c|c|c|c|}
\hline Group & $\begin{array}{l}\text { Primi } \\
\text { gravida }\end{array}$ & $\begin{array}{l}\text { Multi } \\
\text { gravida }\end{array}$ & $\begin{array}{l}\text { PIH \% } \\
\text { in } \\
\text { various } \\
\text { groups }\end{array}$ & $\begin{array}{l}\text { Results of } \\
\text { logistic } \\
\text { regression } \\
\text { analysis }\end{array}$ \\
\hline Control & $\begin{array}{l}10 \\
(6.8 \%)\end{array}$ & $\begin{array}{l}7 \\
(4.7 \%)\end{array}$ & $11.64 \%$ & \multirow{5}{*}{$\begin{array}{l}\text { Regression } \\
\text { coefficient- } \\
1.504 \\
\text { P<0.0001 } \\
\text { ODDS } \\
\text { RATIO } 4.5 \\
95 \% \text { CI: } \\
1.99-10.18\end{array}$} \\
\hline $\begin{array}{l}\text { Study } \\
\text { group A } \\
\text { without } \\
\text { intervention }\end{array}$ & $\begin{array}{l}19 \\
(21.11 \%)\end{array}$ & $9(10 \%)$ & $31.11 \%$ & \\
\hline $\begin{array}{l}\text { Study B } \\
\text { with } \\
\text { intervention }\end{array}$ & $\begin{array}{l}5 \\
(5.67 \%)\end{array}$ & $\begin{array}{l}4 \\
(4.4 \%)\end{array}$ & $10 \%$ & \\
\hline $\begin{array}{l}\text { Total } \\
\text { patients in } \\
\text { each group }\end{array}$ & 116 & 210 & & \\
\hline $\begin{array}{l}\text { Incidence } \\
\text { rate of PIH } \\
\text { in different } \\
\text { group }\end{array}$ & 29.31 & 9.52 & & \\
\hline
\end{tabular}

Table 3 shows that incidence of PIH in control group is $11.64 \%$ whereas in study group $\mathrm{A}-31.11 \%$ and study group B it is $10 \%$.
Incidence of complications is significantly higher in study group A than study group B as well as there is significant difference in the incidence of preterm birth between both the groups.

Also ROC curve analysis of SOD in PIH was done to calculate the cut off value of SOD to determine its role in prediction of development of PIH.

These results were not statistically significant curve shows that when all off value of SOD $<0.5780 / \mathrm{mg}$ of protein, sensitivity is $66.07 \%$ and specificity as $51.85 \%$.

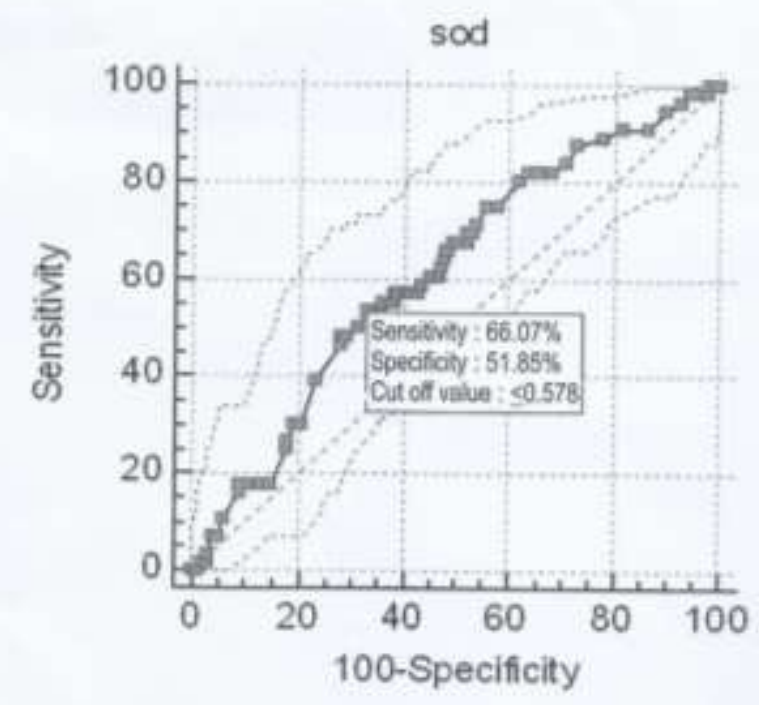

Area under curve 0.618 ; $95 \%$ C.I.: 0.563 - 0.671; P - O.0034

Figure 1: ROC curve.

Table 4: Incidence of PIH in various groups before and after treatment.

\begin{tabular}{|llllllll|}
\hline Patients & $\begin{array}{l}\text { Mild } \\
\text { PET }\end{array}$ & Severe PET & $\begin{array}{l}\text { Abruption } \\
\text { placentae }\end{array}$ & $\begin{array}{l}\text { Antepartum } \\
\text { eclampsia }\end{array}$ & IUGR & Preterm birth \\
\hline $\begin{array}{l}\text { Control } \\
10.96 \%\end{array}$ & $0.68 \%$ & $2.7 \%$ & $0 \%$ & $17.12 \%$ & $68.59 \%$ & $31.5 \%$ \\
\hline $\begin{array}{l}\text { Study group A } \\
\text { without intervention }\end{array}$ & $27.78 \%$ & $3.33 \%$ & $6.67 \%$ & $1.11 \%$ & $17.78 \%$ & $86.7 \%$ & $13.3 \%$ \\
\hline $\begin{array}{l}\text { Study B with } \\
\text { intervention }\end{array}$ & $8.89 \%$ & $1.11 \%$ & $3.33 \%$ & $0 \%$ & $13.3 \%$ & $90 \%$ & $10 \%$ \\
\hline Total & 49 & 5 & 13 & 1 & 53 & 259 & 67 \\
\hline
\end{tabular}

\section{DISCUSSION}

The incidence of pre-eclampsia and eclampsia in primi is $29.31 \%$ and multipara $-9.52 \%$. It is in accordance with study of Pandey $\mathrm{S}$ et al.

The mean level of SOD at 20 weeks in study group was much less as compared to control group. It also showed that SOD in group A at 32 weeks is much less as compared to group B in which intervention was given. These results were highly significant and hence in our study it was shown that SOD enzymes levels improve significantly at 32 weeks after giving intervention. These results are in accordance with previous studies done by Kharbs et al, Want V, Nnodim et al, Mert I.

SOD enzyme levels are strongly correlated with development and severity of PIH, so patients' outcome 
given antioxidant (In our study Vit. C - 1000mg IOD) in already reduced antioxidant state $4 \mathrm{~s}$ i.e. decreased SOD level, was studied. Intervention was given in patients with reduced level of SOD at 20 weeks in form of Vit C $1000 \mathrm{mg}$ IOD; patient was reassessed at 32 weeks by changes in USG - Doppler and measurement of SOD from our study. ${ }^{3}$

It was seen that patient who reviewed intervention in already low antioxidant status- only $10 \%$ cases developed into PIH in contrast to group in which intervention not given $31.11 \%$ developed; these values are statistically significant. These values are statistically significant. This shows that Vit. C $1000 \mathrm{mg}$ IOD when given in patients with already reduced SOD status has a role in prevention of PIH and decreasing its severity. This is in accordance with study of Dewi Rumiris, Yuditiya Parwosymu, Norohyomowibowo, Antonio farina, Akihiko Seikizauma, 2006. ${ }^{4}$

ROC curve analysis of SOD in prediction of PIH shows that SOD enzyme is a good but not an excellent discriminator between control and cases (PIH) and can be used for predicting high risk pregnancies.

It is seen that in the RCTs regarding role of antioxidants conducted to date, the antioxidant supplements were given at too late stage of gestation. In a RCT reported in the US, antioxidant supplementation was started earlier in pregnancy than in other trials $\sim 14-18$ weeks onwards, however, no RCT has yet addressed. Prophylaxis over periconceptional study in US women indicating period, despite results from a large observational study in US women indicating that regular use of multivitamins preparation in periconceptional period was known to cause $45 \%$ reduction in preeclampsia risk. ${ }^{5,6}$

\section{CONCLUSION}

Since, preeclampsia is multifactorial disorder in which oxidative stress plays very important role in pathophysiology amongst various other factors. Hence,
10 screens out patients by assessment of their antioxidant status by measurement of SOD enzyme levels provides a test for screening high risk cases who are at risk of developing into PIH. The antioxidant supplementation to such patients who already have reduced anti-oxidant status definitely has role in decreasing incidence of PIH and its severity.

Funding: No funding sources Conflict of interest: None declared

Ethical approval: The study was approved by the Institutional Ethics Committee

\section{REFERENCES}

1. Walsh SW. Maternal-placental interactions of oxidative stress and antioxidants in preeclampsia, Semin Reprod Endocrinol. 1998;16(1):93-104.

2. Davidge ST. oxidative stress and altered endothelial cell function in preeclampsia. Seminars in reproductive endocrinology. 1998;16(1):65-73.

3. Padayatty SJ, Katz A, Wang Y, Eck P, Kwon O, Lee $\mathrm{JH}$, et al. Vitamin $\mathrm{C}$ as an antioxidant: evaluation of its role in disease prevention. J Am Coll Nutr. 2003;22(1):18-35.

4. Rumiris D, Parwosymu Y. Lower Rate of Preeclampsia After Antioxidant Supplementation in Pregnant Women with Low Antioxidant Status. Hypertension in Pregnancy. 2006;25(3).

5. Bodnar LM, Tang G, Ness RB. Periconceptional Multivitamin Use Reduces the Risk of Preeclampsia. American Journal of Epidemiology Advance Access. 2006:1-8.

6. Agnihotri M, Pathak SK. Free Radical Induced Oxidative Stress in Pre- Eclampsia and Eclampsia of Pregnancy. The Internet Journal of Health. 2013;14.

Cite this article as: Tripathi N, Singh A, Pandey K, Singh N, Arya S. Role of anti-oxidants to reduce free radical induced injury in preeclampsia. Int $\mathrm{J}$ Reprod Contracept Obstet Gynecol 2016;5:3795-8. 